It is impossible to put in a short space all the reasons which led Sachs to draw a sharp distinction between the behaviour of water entering into preformed capillary cavities or interstices, and water which is "imbibed," i.e. forces its way between the molecules or micellæe of an organised body. It may be remarked that cases may easily be supposed where it would be difficult to draw the line, and it is certainly not easy to see why "imbibed" water should be held less fast than water in capillary interspaces. It is just here, in fact, that the assumption of the extraordinary conductibility of wood comes in.

It is clear, then, that the great difficulty which is to be put aside by assuming, with Sachs, that the water of transpiration is held in a peculiar mobile condition in the substance of the cell-walls, is that of accounting for the great height of the water columns in tall trees. The old capillary theory will not explain this away, because, although the requisite columns of water could be sup. ported, the water could not be moved as required.

Frederick Elfving brought forward an awkward objection to Sachs's theory a couple of years ago. By stopping up the lumina of the cells and vessels in such a manner that the edges of the cut elements could still be exposed, it was shown that no water could be pressed through a piece of wood. He showed, morcover, that coloured solutions passed into the cavities of the wood-cells through the thin membranes of the bordered pits, butas must be concluded from his results--not through the thick substance of the walls. Objections have been raised to some details, but it seems difficult to avoid the conclusion that Elfving's results contradict every other view than that the water passes through the thin membranes of the bordered pits, and through the cavities of the elements, and not through the main substance of the walls of the lignified cells.

Elfving has recently published a paper on this subject ("Acta Soc. Scient. Fen. nicke," t. xiv. 1884) pro posing an important modification of the views hitherto held. It is needless to go into the reasons why the theory of gaseous pressures generally must be abanconed, even in its later form, as was Boehm's air-pump theory beforc ; though it is instructive to note that much insight into the physics of the plant may be obtained by a careful study of Boehm's, and especially Hartig's, views, and the various criticisms of them. We may, however, summarise Elfving's remarks, and the chief points for criticism in all the views, as follows.

In advocating the "imbibition theory," no proof is afforded that the lumina of the elements of the living wood are ever entirely devoid of water: some water is always present at least in the cells. This does not go against either theory; but the proof that the cells were at any time entirely devoid of water would decidedly support the "imbibition theory."

Enough has already been said as to why we may reject the theory of atmospheric pressure.

Confining our attention to the wood of Conifers, for obvious reasons, the chief facts are as follows. As the young wood-cells lose their protoplasm, water, containing air in solution, occupies the cavity, and bubbles of air are formed alternating with drops of water - in fact, a series of "chapelets de Jamin" are formed; only, instead of being simple and in one long tube, each one is complex, and the broken water-columns are confined in closed chambers permeable (to water, but not to air) at the bordered pits, and therefore communicating. One advantage of this is that the "chapelets" are less easily broken.

Elfving then passes on to show that, according to Jamin's researches, these columns of water may be of any height likely to come under our consideration: we have thus no more difficulty as to the suspension of the continuous columns of water-continuous, that is, in a serpentine course. The molecules of water can pass between the supporting bubbles of air as if they had no weight, since it is only the movement of the masses of water as a whole in the longitudinal direction which is prevented by the capiliary forces in the "chapelet de Jamin"; the individual particles of water have perfect freedom of motion, and will of course travel towards the transpiration surfaces.

Elfving then goes on to show that many other facts are explained by his theory, and especially the loss of conductivity for water in branches cut off in the air. We must refer the reader to the original paper, however, for further details.

In conclusion, while there is no doubt that Sachs's ingcnious "imbibition theory" of the ascent of the water in plants was startling, on account of the bold assumption of the peculiar condition of the water in the ce!l-walls, it must not be forgotten that it was suggested after a series of profound researches into the properties of wood, and by a master-mind which had tried all previous explanations and found them wanting; moreover, the strangeness of an hypothesis is in itself no argument, and so long as the "imbibition theory" explains more facts than any other it must be accepted on those terms.

If, however, the theory proposed by Elfving turns out to cxplain the same number of facts equally well, it will have to be allowed that it rests on a foundation of a very different nature, and which can be experimentally tested. It is not easy to suggest a distinctive name for the latter theory ; perhaps it might be known as the "step" theory, since the intra-cellular movement of the water up to the leaves seems to be somewhat of the nature of a series of ascents by steps, or from side to side. We recommend the subject to the careful consideration of those physicists who have an adequate knowledge of the structure of plants.

\section{NATURAL SCIENCE IN TASMANIA}

A LTHOUGH the scientific energy of Tasmania is not $A$ all that could be wished for, still the Royal Society of Tasmania is doing something to keep the flame alive. It is much to be wished that some of its hundred Fellows would devote themselves to an investigation of the flora and fauna of their districts, about which there is still much to be learnt. The Proceedings of the Royal Society for 1882 and 1883 have just reached us. The volume for 1882 contains over I80 pages, and is illustrated by four creditably executed fithographic plates. The details of the proceedings at the monthly meetings of the Society are first given, then follow the papers, the more important of which are as follows:-On the fishes of Tasmania, with a classified catalogue of the hitherto recorded species, by Robert $\mathrm{M}$. Johnston. Incidentally he mentions that out of a population of 120,000 persons, it is estimated that about 1050 pcrsons are directly dependent upon the capture and sale of fish. Hobart is the chief centre of the industry. Out of the 188 known species, about one-third are regarded as good edible fish, though only some $2 \mathrm{I}$ of these are sufficiently abundant to be ranked as of importance from a food point of view, and of these, some, like the sprat and anchovy, are quite neglected, from want of knowledge and want of energy. Among the so-called fresh-water fish, Lates colonorum, though a well-known fish in Australian waters, is confined, so far as is yet known, in Tasmania to one small river discharging into Anson's Lagoon, on the north-east of the island. Though not a sea-going fish, it is chiefly to be found at the mouth of small streams whose connection with the sea is frequently closed by shifting sand-bars; and possibly in this way it became originally acclimatised to fresh water. The fresh-water herring (Prototroctes marcena $)$ is said to be the finest of the native fresh-water fishes; chiefly insect-feeders, they give the angler some sport. Some fourteen years ago they suddenly almost disappeared 
from most of the rivers where formerly they had abounded, and thousands were seen floating dead down the stream, destroyed apparently by some species of Saprolegnia. It is satisfactory to note that of introduced fish the colonists have now a fine non-migratory trout (brown trout) and a splendid sea-going migratory salmon, the exact species of which is still involved in uncertainty. Among marine fishes special mention is made of the Barracouta (Thyrsites atun) and Kingfish (Th. solandri), which abound all the year round; but there would appear to be next to no attempt to cure the fish for the foreign market. Mr. R. Etheridge contributes a paper on Trilobites and other fossils from the Lower Silurian rocks of the Mersey River district, Tasmania. Several new species are. described, and the species of Trilobites and Brachiopods are figured. Lieut. Beddome describes sixteen new species of Tasmanian shells, and Messrs. Higgins and Petterd some new species of Antechini and Muridæ.

The volume for 1883 contains 65 pages and but few memoirs. Messrs. Higgins and Petterd describe in it some new Tasmanian mice, and the same authors contribute an interesting account of a new cave-inhabiting spider. This species (Theridion troglodytes) was found in a recently-discovered cave in the Chudleigh district. The cave was found to consist of several chambers, in the innermost of which the spiders were found. The floor of the cave is about thirty feet below the level of the present entrance, and is only reached by two well-like descents of from fourteen to sixteen feet each, connected by low passages. There was also found a large deposit of mammalian remains, some in the crevices of the rocks, others embedded in the earthy and stalagmitic floor. These remains can be all referred to non-carnivorous marsupials and mice. It is strange that no insects were found, but the cave would seem to be worth a more detailed investigation, which the authors promise, adding that the stalactites surpassed in beauty those of the well-known Chudleigh Caves.

\section{EXPLORATIONS IN ICELAND}

THE Lava Desert of ÓdáðaHraun

I N about the central region of Iccland, on the northern skirts of Vatnajökull, the largest glacier in Europe, is situated the most extensive occidental lava desert, the Ódádahraun, covering a total area of about 16,000 square miles English. The whole of this wilderness is almost entirely one barren mass of lava, though here and there the traveller may observe patches filled with drifts of sand giving growth to some few stray tufts of upright lymegrass (tlymus arinarius); but frequently a journey may be made through this region for days together without one single blade of grass being sighted. The total absence of vegetation and water in these tracts makes travelling here excessively arduous and risky, and these difficulties are still more aggravated by the elevation of the country above the level of the sea, in consequence of which it may frequently happen, even in the midst of summer, that the traveller is enveloped in blinding snowstorms, which preclude all attempts at further progress while they last. In such predicaments no reliance can be placed on the compass, because of iron entering so very largely into the composition of the lavamasses. Hence this desert has hitherto remained a terra incognita, and has never been surveyed; yet volcanoes of gigantic dimensions are found here, and many natural phenomena beside, which command great scientific interest. Not only to the world of science has Odád̆ahraun been an unknown region, but even the inhabitants of the surrounding country-side have at all times entertained the most vague and ignorant ideas concerning it. For ages they pictured it to themselves as the home of trolls and mountain sprites. Even as late as the present century it was commonly believed that up among the volcanoes there were to be found verdant valleys containing a whole population of outlaws; a belief which took its rise and received its fortification from the fact that jets of steam issuing from the crevassed mountains were taken by distant beholders for smoke ascending from the chimneys of the abodes of outlaws. The outlaws themselves were pictured to the imagination as either human beings of a savage type, or as some preterhuman race of gigantic strength. So firmly ingrained in the people was this belief, that even as late as I 830 an armed expedition was despatched from Mývatn for the purpose of exploring the haunts of these communities of outlaws, the result of which, I need not say, proved discouraging.

In ancient times one of the highways of the country ran across the northern portion of Odáðahraun, which early records show the bishops of Skálholt to have been in the habit of taking on their visitation tours to the east country. This road was used for the last time in 1736 , but has been lost since, and now no one is able to point out its locality and direction. Across the southern portion of the lava no attempt at forcing a passage had ever been made by man until a certain adventurer named Pjetur Brynjúlfsson, in 1794 , succeeded in threading his way from the East Fjörds westward betwcen the lava and the northern spurs of Vatnajökull, until he struck the road of Sprengisand, which traverses the country right across from the northland to the southland quarter. In 1838 Björn Gunnlaugsson, the famous constructor of the best map of Iceland, undertook a journey of exploration to Odádahraun, but fell in with such tempestuous weather that all his attempts at exploration were defeated, and he himself barely escaped with his life. Next year he repeated his journey, and, being favoured with better weather, he forced his way from the south up into the boundary line between the lava and the glacier, and pushed on some distance to the eastward. In this trip he attained some positive results. In I 840 a Danish naturalist, Schythe, intending to explore this region, took the same route, but was overtaken by such excessively stormy weather that, after having lost most of his horses, he just escaped with extreme difficulty into the countryside of Jökuldal in the east country. From this time no attempt at reconnoitring this wild country was hazarded until the stupendous explosion from Askja in 1875 gave such surprising evidence of the enormous activity of the volcanoes in these wildernesses. This year Mr. Watts made his way right across Vatnajökul, striking Askja in his descent over its northern spurs. Shortly afterwards Askja was visited by an Icelander, Jón Thorkelsson, who made his way up to it on foot in the midst of winter. In the summer of 1876 the Danish Government despatched Prof. Johnstrup with a party of scientific men to these volcanic wastes, who explored the region of Askja and constructed a map of the volcanoes. Prof. Johnstrup's is the only scientific exploration that ever yet was carried out in Ódádahraun. At more recent dates Askja has been visited by scveral English tourists, such as Messrs. Lock, Coles, and Morgan. In 1880 several farmers from the districts of Myvatn and Barbardal made the complete circuit of Odá⿱一𫝀hraun. But, in spite of all such reconnoitring trips, the whole of Odádahraun is practically unknown yet, with the exception of the corner occupied by Askja.

Instructed by the Government, I have now for several years been engaged in surveying the upland tracts of Iceland, exploring the country geographically, and examining into its geological structure and character generally, This summer I resolved to attempt an exploration of Ódárahraun with such means as I had at my command. With a view to more expeditiously effecting my purpose, I adopted the plan of sclecting certain fixed stations on grassy spots here and there about the wildernesses which 